\title{
AUTUMN MIGRATION OF JUVENILE WHITE PELICANS FROM WESTERN CANADA
}

\author{
by Kees Vermeer, Canadian Wildlife Service, Edmonton
}

Recoveries of 112 White Pelicans (Pelecanus erythrorhynchos) banded at Quill $\left(51^{\circ} 50^{\prime} \mathrm{N} ; 104^{\circ} 20^{\prime} \mathrm{W}\right)$ and Redberry $\left(52^{\circ} 40^{\prime} \mathrm{N} ; 107^{\circ} 10^{\prime} \mathrm{W}\right)$ lakes, Saskatchewan, showed that pelicans in the autumn migrate SSE from Saskatchewan to Texas and Louisiana (Houston, 1967, 1968). In July 1968, 900 young White Pelicans were banded at Primrose Lake $\left(54^{\circ} 57^{\prime} \mathrm{N} ; 109^{\circ}\right.$ $\left.42^{\prime} \mathrm{W}\right)$, Saskatchewan, and 45 at Stum Lake $\left(52^{\circ} 16^{\prime} \mathrm{N} ; 123^{\circ} 01^{\prime} \mathrm{W}\right)$, British Columbia, for the purpose of obtaining information on the autumn migration of pelicans breeding farther north and west than those at Quill and Redberry lakes. Judging from six recoveries, young pelicans raised at Primrose Lake migrate along a similar route (Fig. 1) as has been observed for those from Quill and Redberry lakes. However, three recoveries of pelicans from Stum Lake indicate that the birds from that colony follow a different flyway, as none had crossed the continental divide (Fig. 1).

The assistance in the banding of pelicans provided by $\mathrm{H}$. Blokpoel and J.A. Keith, Canadian Wildlife Service, J. O. Keith, U.S. Fish and Wildlife Service, D. W. Anderson, University of Wisconsin, C. Scott, Alberta Fish and Wildlife Division, and personnel from the Air Force Base at Cold Lake is much appreciated.

\section{LITERATURE CITED}

Houston, C. S. 1967. Saskatchewan bird banders, Judge J. A. M. Patrick (1873-1943). Blue Jay, $25: 172-174$.

Houston, C. S. 1968. Saskatchewan bird banders, William I. Lyon and H. E. McArthur. Blue Jay, $26: 185-187$.

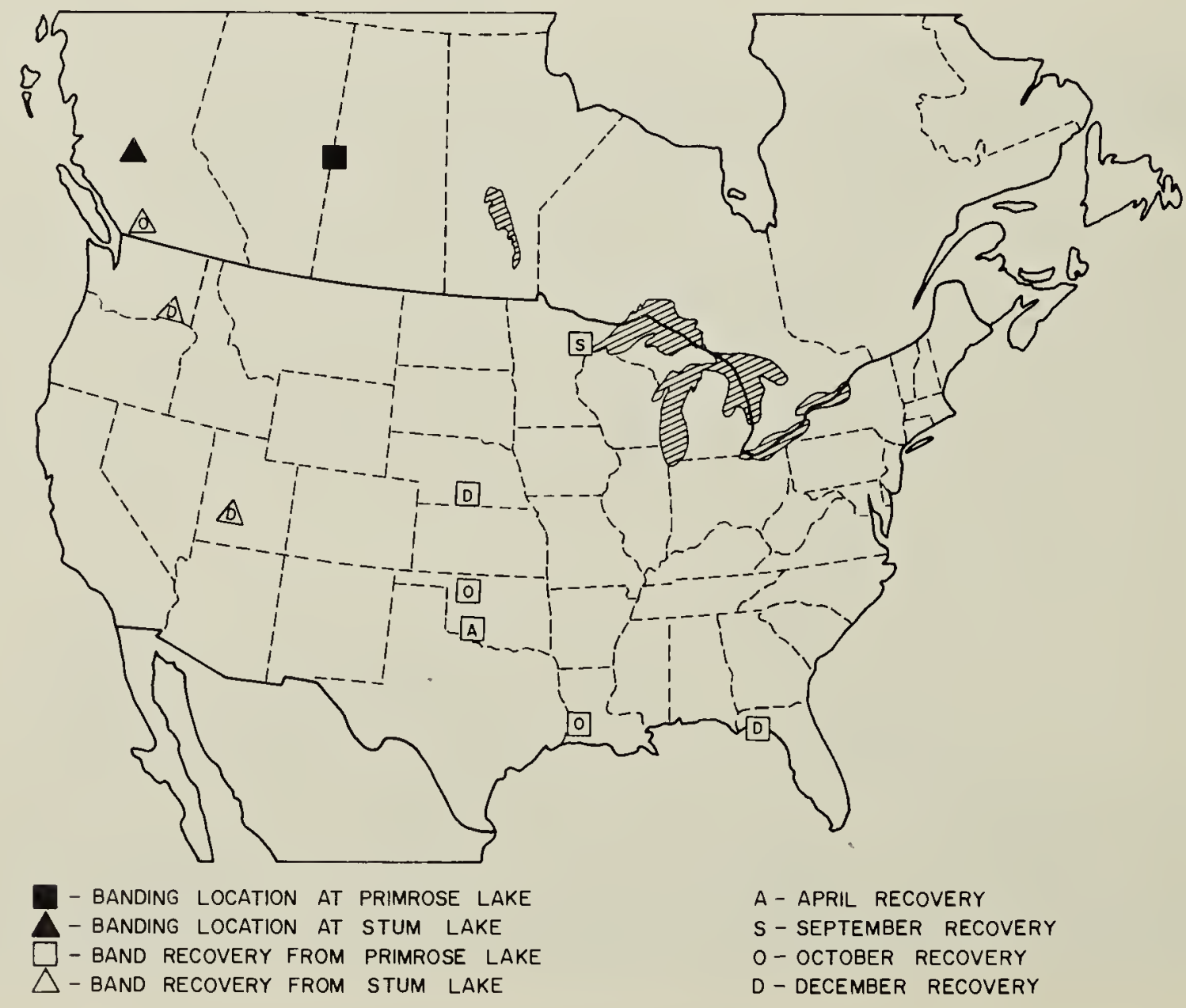

Fig. 1. Recoveries of juvenile White Pelicans banded at Primrose and Stum lakes. 